\title{
Correction to: The enhanced recovery after surgery (ERAS) protocol to promote recovery following esophageal cancer resection
}

\author{
Apurva Ashok ${ }^{1}$ - Devayani Niyogi ${ }^{1} \cdot$ Priya Ranganathan $^{2} \cdot$ Sandeep Tandon ${ }^{3} \cdot$ Maheema Bhaskar $^{3}$. \\ George Karimundackal ${ }^{1}$ - Sabita Jiwnani ${ }^{1} \cdot$ Madhavi Shetmahajan $^{2}$. C. S. Pramesh ${ }^{1}$ (1)
}

Published online: 25 March 2020

(c) The Author(s) 2020

\section{Correction to: Surgery Today https://doi.org/10.1007/s00595-020-01956-1}

The article The enhanced recovery after surgery (ERAS) protocol to promote recovery following esophageal cancer resection by Apurva Ashok, Devayani Niyogi, Priya Ranganathan, Sandeep Tandon, Maheema Bhaskar, George Karimundackal, Sabita Jiwnani, Madhavi Shetmahajan, and C. S. Pramesh was originally published electronically on the publisher's internet portal https://link.springer.com/ article/10.1007/s00595-020-01956-1 on 11 February 2020 without Open Access.

With the author(s)' decision to opt for Open Choice, the copyright of the article changed on March 10, 2020 () The Author(s) 2020 and the article is forthwith distributed under the terms of the Creative Commons Attribution 4.0 International License (https://creativecommons.org/licenses/ by/4.0/), which permits use, duplication, adaptation, distribution and reproduction in any medium or format, as long as you give appropriate credit to the original author(s) and the source, provide a link to the Creative Commons license, and indicate if changes were made.

The original article has been corrected.

Open Access This article is licensed under a Creative Commons Attribution 4.0 International License, which permits use, sharing, adaptation, distribution and reproduction in any medium or format, as long as you give appropriate credit to the original author(s) and the source, provide a link to the Creative Commons licence, and indicate if changes were made. The images or other third party material in this article are included in the article's Creative Commons licence, unless indicated otherwise in a credit line to the material. If material is not included in the article's Creative Commons licence and your intended use is not permitted by statutory regulation or exceeds the permitted use, you will need to obtain permission directly from the copyright holder. To view a copy of this licence, visit http://creativecommons.org/licenses/by/4.0/.

Publisher's Note Springer Nature remains neutral with regard to jurisdictional claims in published maps and institutional affiliations.

The original article can be found online at https://doi.org/10.1007/ s00595-020-01956-1.

C. S. Pramesh

prameshcs@tmc.gov.in

1 Division of Thoracic Surgery, Department of Surgical Oncology, Tata Memorial Centre, Tata Memorial Hospital, Homi Bhabha National Institute, Parel, Mumbai 400012, India

2 Division of Thoracic Surgery, Department of Anesthesiology, Critical Care and Pain, Tata Memorial Centre, Homi Bhabha National Institute, Mumbai, India

3 Division of Thoracic Surgery, Department of Pulmonary Medicine, Tata Memorial Centre, Homi Bhabha National Institute, Mumbai, India 